\title{
TRADISI KRITIK TAFSIR: Diskursus Kritisisme Penafsiran dalam Wacana Qur'anic Studies
}

\author{
MK. Ridwan \\ Institut Agama Islam Negeri Salatiga \\ e-mail: mkridwan13@gmail.com
}

\begin{abstract}
This paper aims to discuss the methodology of interpretation criticism in the qur'anic studies discourse. As new plots in the Qur'an studies, the interpretation criticism has not been much sought after by Qur'anic scholars. As a consequence, in methodological discourse has not yet found a definite method can be used to criticize an interpretation. As for the thought-provoking critique of the interpretation for this still are sporadic and likely are political-ideological. For that, it needs special attention in developing area studies the Quran towards the study criticism of interpretation. Finally, this paper gives the conclusion that, in the discourse of criticism the methodological framework needed interpretation, as a step towards the operational interpretation of criticism. So, the criticism was done not nuanced political-ideological, but able to uphold the values of objectivity, comprehensiveness, scientific and systematic. There are at least four operational steps in carrying out work interpretation of criticism of the region of ontology, epistemology, and axiology i.e; Firstly, the critic must understand the substance of exegesis are an interpretation as process and interpretation as a product. Secondly, understand the construction of criticism interpretation, namely the construction of the historicity of the critique, the base of criticism, the purpose of criticism, as well as the principles and parameters of criticism. Thirdly, start working with two regions exegesis critique work i.e; intrinsic and extrinsic criticism. Fourthly, give the evaluation and assessment of the object of study of criticism that is good and decent, or perverted and unworthy of being used.
\end{abstract}

\begin{abstract}
Abstrak: Tulisan ini bertujuan untuk mendiskusikan metodologi kritik tafsir dalam diskursus wacana Qur'anic Studies. Sebagai wilayah garapan baru dalam studi al-Qur'an, kritik tafsir belum banyak diminati oleh kalangan sarjana alQur'an. Akibatnya, dalam wacana metodologis belum banyak ditemukan metode baku yang dapat digunakan untuk mengkritisi sebuah tafsir. Adapun pemikiran kritik tafsir selama ini masih bersifat sporadis dan cenderung bersifat politisideologis. Untuk itulah dibutuhkan perhatian khusus dalam mengembangkan wilayah studi al-Qur'an ke arah studi kritik tafsir. Akhirnya, tulisan ini memberikan kesimpulan bahwa, dalam diskursus kritisisme penafsiran, dibutuhkan kerangka metodologis sebagai langkah operasional kritik tafsir. Sehingga, kritik yang dilakukan tidak bernuansa politis-ideologis, namun mampu mengedepankan nilai-nilai objektivitas, komprehensivitas, ilmiah dan sistematis. Setidaknya terdapat empat langkah operasional dalam melaksanakan kerja kritik tafsir yang bermuara pada wilayah ontologis, epistemologis, dan aksiologis yaitu; Pertama,
\end{abstract}


kritikus harus terlebih dahulu memahami hakikat tafsir yakni tafsir sebagai proses (interpretation as process) dan tafsir sebagai produk (interpretation as product). Kedua, memahami konstruksi kritik tafsir, yaitu historisitas kritik, landasan kritik, tujuan kritik, serta prinsip dan parameter kritik. Ketiga, memulai kerja kritik tafsir dengan dua wilayah kerja yaitu; kritik intrinsik dan kritik ekstrinsik. Keempat, memberikan evaluasi dan penilaian terhadap objek kajian kritik yaitu, baik (mahmūd) dan layak pakai (maqbūl), atau menyeleweng (munḥarif) dan tidak layak digunakan (mardūd).

Keywords: metodologi; kritik tafsir; studi al-Qur'an

\section{A. Pendahuluan}

Wacana studi al-Qur'an (qur'anic studies) di berbagai penjuru dunia baik di kalangan Muslim (insider) maupun non-Muslim (outsider) telah mengalami kemajuan yang cukup signifikan jika dibandingkan dengan konteks masa silam. Kemajuan ini disebabkan oleh perubahan-perubahan situasi tak terhindarkan yang tidak disebut secara eksplisit di dalam al-Qur'an. ${ }^{1}$ Konteks perubahan zaman tersebut telah "memaksa" kaum Muslim untuk terus berijtihad dalam menafsir al-Qur'an agar nilai-nilai yang dikandungnya senantiasa menzaman, membumi dan kontekstual. Pada akhirnya, perkembangan studi al-Qur'an menjadi sangat kompleks dengan berbagai inovasi-progresif baik pada aspek "tafsir" (exegesis) maupun aspek "metodologis" (the theory of interpretation). ${ }^{2}$

Kehadiran teks al-Qur'an, telah melahirkan pusat lingkaran wacana keagamaan yang tak kenal henti, bahkan semakin membesar membentuk imperium raksasa peradaban. Dinamisasi studi al-Qur'an tersebut, setidaknya memiliki dua kecenderungan, pertama; gerak sentripetal (bergerak menuju pusat) dan; kedua, gerak sentrifugal (bergerak menjauhi pusat). Melalui gerak sentripetal, teks al-Qur'an selalu menjadi rujukan utama untuk memperoleh tempat dan pembenaran mengenai berbagai persoalan kemausiaan. Al-Qur'an dalam konteks ini memiliki daya kuat gravitasi dan kemampuan akomodatif, sehingga sekian banyak madzab dan silang pendapat tentang keislaman, semuanya merasa selalu dipayungi oleh kebenaran al-Qur'an. Sementara dalam gerak

1 J.J.G. Jansen, The Interpretation of the Koran in Modern Egypt (Leiden: E.J. Brill, 1974), h. 4.

${ }^{2} \mathrm{Al}-$ Farmawy telah melakukan penelitian terhadap berbagai model penafsiran yang digunakan oleh para ulama dan menyimpulkan bahwa setidaknya terdapat empat metode yang digunakan dalam menafsirkan al-Qur'an, yaitu; tahlili (analitis/rinci), ijmali (global), muqaran (perbandingan), dan mawḍūi (tematik). Abu Hayy al-Farmawy, al-Bidāyah fi al-Tafsìr al-Mawḍūi (Kairo: Matba'ah alHadarah al-Arabiyah, 1990). 
sentrifugal ${ }^{3}$, teks al-Qur'an selalu menjadi dorongan inspiratif yang sangat kuat untuk terus menerus melakukan penafsiran dan pemaknaan, menjelajah, melakukan pengembaraan intelektual dalam mengungkap kandungannya. ${ }^{4}$

Melalui gerak sentrifugal inilah, wacana exegesis (tafsir) al-Qur'an berkembang menjadi suatu tradisi dan disiplin ilmu mandiri yang ditransmisikan dari generasi ke generasi. Karena teks-teks al-Qur'an meskipun secara lahiriyah sama dengan teks-teks lainnya, namun al-Qur'an sebagai kalamullah memiliki karakteristik unik yaitu sebuah teks yang melampaui teks (beyond the text). Sebuah teks yang memiliki sensitivitas pemaknaan tingkat tinggi. Jika ditafsir akan menghasilkan pluralitas makna sesuai "keinginan" sang penafsir. Hal ini tidak terlepas dari ungkapan Ali bin Abi Thalib, bahwa "al-qur'ān bayna daftay al-muṣhāfla yantiq, innamā yantiqu (yatakallamu) bihi al-rijāl". Yakni, tanpa adanya campur tangan manusia, al-Qur'an tidak akan pernah bisa berfungsi apaapa. Sehingga al-Qur'an akan membawa banyak sudut pandang (al-Qur'ān hammal aujuh) dan beragam kemungkinan dalam penafsirannya sesuai dengan kecenderungan mufasirnya. ${ }^{5}$

Lahirnya ragam penafsiran inilah yang kemudian memunculkan diskursus kritisisme penafsiran. Meskipun secara historis, kritisisme dalam wacana alQur'an telah dimulai sejak masa Nabi Muhammad, meskipun masih dalam bentuknya yang abstrak (embriotik). Pada tahapan selanjutnya, seiring dengan maraknya penafsiran sektarian, diskursus kritisisme penafsiran semakin menguat dan menemukan bentuknya. Ditambah dengan menguatnya paradigma absolutisme penafsiran, yaitu menganggap bahwa penafsiran seseorang atau kelompok tertentulah yang paling benar. Berangkat dari realitas tersebut, diskursus kritisisme penafsiran harus menjadi mega proyek bersama dalam rangka menjaga universalitas al-Qur'an sebagai hudan li I-nās.

\footnotetext{
${ }^{3}$ Gamal al-Banna, memberikan komentar terhadap gerakan ini dengan menyatakan bahwa kecintaan umat Islam terhadap al-Qur'an ikut mengalami pergeseran, dari kecintaan terhadap alQur'an kepada kecintaan terhadap penafsiran al-Qur'an. Menurutnya, pergeseran tersebut menunjukkan ketergelinciran dan perubahan orientasi dari yang asli menuju yang mewakili. Gamal alBanna, Evolusi Tafsir: Dari Zaman Klasik hingga Modern, terj. Novriatoni Kahar (Jakarta: Qisthi Press, cet II 2005), h. xi.

${ }^{4}$ Komaruddin Hidayat, Memahami Bahasa Agama; Sebuah Kajian Hermeneutik (Jakarta: Paramadina, 1996), h. 15.

${ }^{5}$ Abdullah Saeed, Interpreting the Qur'an; Towards a Contemporary Approach (New York: Routledge, 2006), h. 102-103.
} 


\section{B. Terminologi Kritik Tafsir}

Istilah "kritik" dapat dipahami dari berbagai sisi. Secara etimologis kata "kritik" berasal dari kata "krites" (kata benda) yang dalam bahasa Yunani Kuno berarti "hakim", karena berasal dari kata kerja "krinein" yang artinya menghakimi. ${ }^{6}$ Dalam bahasa Inggris, istilah ini dikenal sebagai "critique" yang berarti "a considered assessment of a literary work". Bisa juga berarti "criticism" yaitu mencela, mengecam atau mengupas. ${ }^{7}$ Sedangkan menurut Kamus Besar Bahasa Indonesia, "kritik" diartikan sebagai proses kecaman, kadang-kadang disertai uraian dan pertimbangan baik buruk terhadap suatu hasil karya atau pendapat. ${ }^{8}$ Sementara dalam bahasa Arab dikenal istilah "al-naqd" dari kata naqadayanqudu-naqdan. Dalam istilah Arab, kata al-naqd digunakan secara beragam seperti, 1) memberikan dengan segera (kontan) sebagai lawan dari penangguhan pembayaran, 2) memilih atau membedakan sesuatu, seperti memilih dirham (mata uang) yang baik dari yang buruk, 3) mengintai sesuatu, 4) mengkritik dengan menyatakan baik atau buruk. ${ }^{9}$

Secara istilah, kata kritik sebagaimana didefinisikan oleh M. H. Abrams dan Geoffrey Galt Harpham adalah suatu usaha dalam menganalisis, menafsirkan, mendefinisikan, mengklasifikasikan dan mengevaluasi sebuah karya untuk ditimbang dan dinilai kesesuaiannya dengan standar kriteria (norma-norma) yang berlaku. ${ }^{10}$ Sebagaimana juga yang telah didefinisikan oleh $\mathrm{H}$. James Jansen, bahwa kritik merupakan usaha-usaha sistematis dalam menemukan kesalahan/ kekurangan terhadap seuatu karya dengan cara menganalisis kemudian memberikan penilaian, evaluasi dan apresiasi terhadapnya. ${ }^{11}$ Sementara Mohammed Arkoun memahami kritik sebagai usaha dalam merekonstruksi dan rekonfi-

6M. A. Rafey Habib, A History of Literary Criticism; From Plato to the Present (United Kingdom: Blackwell Publishing, 2005), h. 9.

${ }^{7}$ Chris Baldick, The Concise Oxford Dictionary of Literary Terms (New York: Oxford University Press, 2001), h. 55.

${ }^{8}$ Tim Penyusun Kamus Pusat Bahasa, Kamus Bahasa Indonesia (Jakarta: Pusat Bahasa Departemen Pendidikan Nasional, 2008), h. 761.

${ }_{9}^{9}$ Ibn Manzur, Lisān al-Arab (Beirut: Dar-Al-Ma'rifah, 1979), h. 4571.

${ }^{10}$ M. H. Abrams and Geoffrey Galt Harpham, A Glossary of Literary Terms, Ninth Edition (USA: Wadsworth Cengange Learning, 2012), h. 61.

${ }^{11} \mathrm{H}$. James Jansen, A Glossary of John Dryden's Critical Terms (Mineapolis: University of Mennesota, 1969), h. 36. 
gurasi struktur nalar dalam menggali pemikiran-pemikiran baru. ${ }^{12}$ Selanjutnya, pemahaman kritik yang lebih radikal muncul dari Ali Harb, yang menyatakan bahwa kritik tidak berarti harus mengungkap kelemahan, atau sekadar mengoreksi dan menggugurkan pendapat, tetapi melampaui dari itu, yakni kritik dipahami sebagai sebuah sistem pembacaan terhadap apa yang belum terbaca (qirā'ah mā lam yuqrā). ${ }^{13}$

Kritik juga dapat dipahami sebagai bentuk progresivitas yang mendasar, dengan selalu mempertanyakan, mengevaluasi, dan mencari berbagai pemikiraan atau alternatif baru untuk mendapatkan berbagai kemungkian yang lebih baik. Immanuel Kant adalah sosok filsuf kritis kenamaan yang telah mengembangkan teori kritik dalam bidang ilmu pengetahuan. Kant menekankan tiga ide besar terhadap budaya kritisisme, yakni critique der reinen vernunft (kritik atas rasion murni), critique der praktischen vernunft (kritik atas rasio praktis), dan critique der urteliskr (kritik atas daya pertimbangan). Kant mencoba mendobrak pemikiran rasional an-sich yang terkungkung oleh dogmatisme. Menurut Kant, kemampuan rasio murni tidak akan mampu mencapai pemahaman realitas secara komprehensif. Karena rasio memiliki keterbatasan yang hanya sampai pada dunia penginderaan (fenomena). Maka, dalam hal ini, Kant memahami "kritik" sebagai sebuah tawaran dalam memaksimalkan kemampuan rasio untuk memecahkan berbagai problem kehidupan manusia dengan menyintesiskan pemikiran rasionalisme dengan empirisme. ${ }^{14}$

Sedangkan, secara metodologis, istilah kritik dapat dipahami sebagai; "the analysis, study, and evaluation of individual works of art, as well as the formulation of general methodological or aesthetic principles for the examination of such works."15 Sehingga, kritik adalah suatu cara atau metode untuk mencari kesalahan (fault-finding) sekaligus untuk memuji (to praise) dengan jalan menela-

\footnotetext{
${ }^{12}$ Mohammed Arkoun, al-Fikr al-Islāmi; Naqd wa Ijtihād (Aljazair: al-Mu'assasash alWataniyah li al-Kitab, 1988).

${ }^{13}$ Ali Harb, Kritik Kebenaran, terj. Sunarwoto Dema (Yogyakarta: LKiS, 2004), h. 11. Istilah kritik telah banyak digunakan oleh para pemikir Muslim kontemporer lainnya seperti; Mohammed Arkoun dengan proyek Kritik Nalar Islami, Muhammad Abed al-Jabiri dengan Kritik Nalar Arab, Nasr Hamid Abu Zayd dengan Kritik Tekstualitas al-Qur'an dan Hassan Hanafi dengan proyek Kiri Islam (al-Yassar al-Islami).

${ }^{14}$ Immanuel Kant, Critique of Pure Reason, terj. Paul Guyer and Allen W. Wood (New York: Cambridge University Press, 2000).

${ }^{15}$ C. Hugh Holman, A Handbook to Literature, Fourth Edition (Indianapolis: ITT Bobbs-Merrill Educational Publishing Company, 1985), h. 106.
} 
ah (to study), mengamati (to observe), membandingkan (to compare), mengkaji (to discuss), menafsir (to interpret), menyeleksi (to classify), meninjau (to review), komentar (to commentary), menilai (to judge), mengevaluasi (to evaluate), dan menikmati (to appreciate). ${ }^{16}$

Oleh karena itu, berdasarkan wacana "kritik" di atas, dapat disimpulkan bahwa setidaknya kritisisme bermuara pada dua fungsi utama yaitu; pertama, al-hukm (judgment) yang berarti memberi penilaian terhadap sesuatu; kedua, altafsir (interpretasi) atau al-tahlil (analisis). Maka, yang dimaksud sebagai "kritik" ialah usaha menganalisis dan mengklasifikasi teks untuk mengetahui seluk beluknya dan menyelami kedalaman kandungannya. ${ }^{17}$ Dengan demikian, kritik diartikan sebagai tanggapan objektif dari seseorang terhadap suatu karya orang lain dengan menguraikan secara rinci baik buruknya sebuah karya berdasarkan argumentasi (dalīl) dan parameter (ḍawābit) yang ilmiah. Maka kritik dapat bersifat menjatuhkan/merugikan (destruktif), juga dapat bersifat membangun (konstruktif). ${ }^{18}$

Sementara itu, istilah 'tafsir' terambil dari bahasa Arab yang secara bahasa

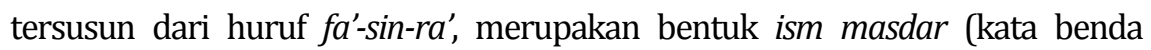
abstrak) dari kata fasara-yufassiru-tafsiran yang artinya menerangkan sesuatu agar menjadi jelas. ${ }^{19}$ Tafsir bisa berarti al-ibānah (menjelaskan), al-kashf (menyingkap), dan al-idhar (menampakkan) makna atau pengertian yang tersembunyi. ${ }^{20}$

Menurut Muhammad Husain al-Dhahabi, tafsir adalah usaha dalam menjelaskan atau menyingkap makna-makna yang terkandung di dalam teks-teks alQur'an sesuai dengan kemampuan manusia.21 Sedangkan, al-Zarkashi (13441392) dalam master piece-nya al-Burhān menjelaskan bahwa tafsir adalah cara manusia untuk memahami al-Qur'an menggunakan perangkat, metode atau

16M. H. Abrams and Geoffrey Galt Harpham, A Glossary of Literary Terms, h. 61-65. 36.

${ }^{17}$ Muhammad Ulinnuha, Rekonstruksi Metodologi Kritik Tafsir (Jakarta: Azzamedia, 2015), h.

${ }^{18}$ Geoffrey Galt Harpham, The Character of Criticism (New York: Routledge, 2006), h. 8.

${ }^{19} \mathrm{Abu}$ al-Husain Ahmad bin Faris bin Zakaria, Mujjam Maqāyis al-Lughah, Juz IV, Tahqiq, Muhammad Harun (Beirut: Dār al-Fikr, 1979), h. 504.

${ }^{20}$ Ibn Manzur, Lisān al-'Arab, h. 3412-3413.

${ }^{21}$ Muhammad Husain al-Dhahabi, al-Tafsir wa 'l-Mufassirūn, Juz I (Kairo: Maktabah Wahbah, 2000), h. 12-13. 
pendekatan —sesuai keinginan mufasir- untuk memperjelas suatu makna yang terkandung di dalam al-Qur'an. ${ }^{22}$

Sehingga, dapat disimpulkan bahwa yang dimaksud dengan kritik tafsir atau lebih tepatnya metode kritik tafsir adalah suatu cara, langkah-langkah atau prosedur yang sistematis, terarah, dan ilmiah untuk melakukan analisis, telaah, evaluasi dan penilaian terhadap suatu produk penafsiran al-Qur'an. Dalam hal ini kritik tafsir bermuara pada usaha mengembalikan peran al-Qur'an sebagai hudan wa shifä'an bagi alam semesta.

\section{Menyelami Historisitas Kritik Tafsir}

Tradisi kritik dalam khazanah intelektual Islam terlebih dahulu dimulai dalam tradisi 'ulūm al-hadith. Istilah kritik menjadi semakin populer ketika ulumul hadits menjadi disiplin ilmu yang mapan dan baku, dengan munculnya pemikiran kritik sanad (naqd al-sanad). Munculnya kritisisme di bidang hadis, dilatarbelakangi oleh munculnya pemalsuan hadis yang disebabkan oleh kepentingan-kepentingan politik, aliran (ideologi) dan ekonomi. Kelompokkelompok yang memiliki kepentingan tersebut sering mencari bahkan membuat hadis-hadis palsu yang dapat dijadikan justifikasi (pembenaran) terhadap tindakan ataupun paham mereka. Hal inilah yang menyebabkan hadis-hadis palsu dengan yang asli menjadi tercambur baur dan sulit untuk dikenali, dipisahkan dan diklasifikasikan. Maka, seiring munculnya pemikiran kritik sanad (naqd al-sanad), telah memberikan angin segar dalam meneliti untuk menguji dan mencari hadis-hadis yang benar-benar autentik berasal dari Nabi SAW. Bahkan tradisi kritisisme hadis tidak berhenti pada wilayah kritik sumber (critical source), tetapi telah sampai kepada kritik matan (naqd al-matan). Hingga pada akhirnya, pemikiran kritis di bidang hadis telah mempertegas perbedaan antara apa yang disebut sebagai sunnah dan ḥadith. ${ }^{23}$

Seiring dengan tradisi kritik dalam 'ulüm al-hadìth, budaya kritisisme mulai menyebar hingga ke bidang penafsiran al-Qur'an. Seiring dengan merebaknya penafsiran al-Qur'an yang bernuansa politis-ideologis, telah "memaksa" umat

${ }^{22}$ Badr al-Dīn al-Zarkashi, al-Burhān fi 'Ulūm al-Qur'ān, tahqiq Ahmad Ali (Qahirah: Dār alHadīth, 2006), h. 22.

${ }^{23}$ Untuk diskusi perbedaan antara sunnah dan hadith, baca Fazlur Rahman, Islamic Methodology in History (Islamabad: Islamic Research Institute, 1995), h. 27. 
Islam untuk bergumul dengan budaya kritis. Meskipun, sebenarnya embrio kritisisme penafsiran atau tradisi kritik tafsir telah dimulai sejak zaman Rasulullah. Hal ini misalnya, bisa dilacak melalui beragam riwayat yang mengisahkan bahwa Rasulullah melakukan kritik terhadap pola pemahaman para sahabat dalam menafsirkan al-Qur'an. Sebagai seorang mubayyin sekaligus mufassir, kritisisme Nabi ini ditujukan untuk mengevaluasi atau meluruskan metodologi (cara memahami), pendapat, dan perbuatan (aktualisasi) yang dilakukan sahabat berdasarkan pemahaman yang kurang tepat terhadap alQur'an.24

Pasca wafatnya Rasulullah, tradisi kritisisme penafsiran al-Qur'an masih tetap berlanjut, meskipun mengalami keredupan akibat menguatnya absolutisme penafsiran oleh kelas sosial yang disebut ulama. Sebagai pemegang otoritas tertinggi — karena didukung oleh penguasa — tidak jarang justru diselewengkan menjadi sebuah otoritarianisme untuk mendikte keislaman masyarakat awam. ${ }^{25}$ Semarak kritisisme penafsiran pada era ini dapat dikatakan lebih bernuansa politik-ideologis. Yaitu lazimnya hanya dilakukan oleh para oposisi yang berusaha merongrong kekuasaan atau sebaliknya; legitimasi kekuasaan atas ideologi tertentu. Sehingga, tradisi kritisisme yang dilakukan oleh generasi awal Islam cenderung bias kepentingan, baik aspek ideologis, politis maupun ekonomis. Kritisisme yang berjalan pun belum terbangun secara sistematis dalam sebuah metodologi kritik yang praktis dan terstruktur, sebagaimana dalam disiplin ilmu hadis. Karenanya kritisisme yang ditemukan masih bersifat sporadis dan belum ada metode baku yang dapat digunakan bagi para pengkaji tafsir untuk melakukan kerja kritisisme penafsiran. ${ }^{26}$

Seiring terjadinya rennaissance di Barat, yaitu dibukanya kran modernisme yang ditandai dengan revolusi industri di Inggris dan revolusi politik di Prancis, serta meningkatnya daya efektifitas dan efisiensi yang mendukung peningkatan ilmu pengetahuan dan teknologi. Telah memberikan angin baru dalam dunia penafsiran al-Qur'an. Perkembangan ilmu-ilmu sosial humaniora yang pesat mencoba dimanfaatkan oleh intelektual Muslim untuk memberikan pendekatan

\footnotetext{
${ }^{24}$ Muhammad Ulinnuha, Rekonstruksi Metodologi Kritik Tafsir, h. 42.

${ }^{25}$ Khaled Abou el-Fadl, Speaking in God's Name; Islamic Law, Authority, and Women (London: Oneworld Publication, 2014), h. 50.

${ }^{26}$ Muhammad Ulinnuha, Rekonstruksi Metodologi Kritik Tafsir, h. 42-43.
} 
dan interpretasi baru terhadap al-Qur'an. Sehingga, tradisi kritisime di era modern telah memunculkan tokoh-tokoh yang mencoba untuk melakukan tawaran metodologi kritik tafsir. Seperti; Amin al-Khuli (1895-1966) dengan teori kritik sastra-nya, Husain al-Dhahabi (1915-1977) dengan teori kritik inhiraf-nya, Muhammad Abu Shahbah (1914-1983) dengan metode kritik isrāiliyat-nya, Fazlur Rahman (1919-1988), seorang intelektual organik asal Pakistan menawarkan metode kritik double movement-nya, Mohammed Arkoun (1928-2010) dengan kritik nalar Islam-nya, M. Abed al-Jabiri (1935-2010) dengan kritik nalar Arabisme-nya, Hassan Hanafi (1. 1935) asal Mesir menawarkan produk hermeneutika fenomenologis-nya, dan Abd al-Wahhab Fayed (19361999) dengan metode kritik al-dakhil-nya serta beberapa tokoh terkemuka lainnya seperti Muhammad Shahrur dan Ali Harb. Meskipun harus dikatakan bahwa gagasan yang dihasilkan tokoh-tokoh tersebut bukanlah sesuatu yang final. Dibutuhkan kritisisme untuk melakukan reformulasi dan restrukturasi, karena metode dan teori mereka masih berserakan dalam berbagai karyanya. Oleh karena itu, menurut M. Ulinnuha berbagai metode yang masih tersebar dan berserakan itu, perlu untuk dikumpulkan, dihimpun, disusun, dan direkonstruksi secara ilmiah dan sistematis, sehingga akan memunculkan bangunan metodologi kritik tafsir yang utuh dan komprehensif.27

\section{Memahami Hakikat Tafsir}

Permasalahan penafsiran al-Qur'an, selama ini masih menyisakan debateable tersendiri di kalangan sarjana Muslim. Argumentasi seputar validitas sebuah penafsiran terkadang menyisakan kekaguman berlebihan oleh sebagian besar pembacanya. Tidak sedikit yang menjadi pengagum bahkan mengkultuskan pemikirannya, dengan menganggap bahwa hanya penafsirannya itulah yang paling benar. Hal ini kemudian menyebabkan terjadinya sakralitas terhadap sebuah penafsiran dan cenderung menempatkan tafsir al-Qur'an sejajar dengan al-Qur'an. Padahal tafsir merupakan teks kedua, karena hasil dari turunan (baca: penafsiran) makna yang dikandung oleh al-Qur'an. Tafsir juga dibatasi oleh konteks-konteks partikular yang mengitari mufasir dan cenderung disesuaikan dengan kondisi dan nalar pemikiran pada saat penafsiran berlangsung. ${ }^{28}$

27Muhammad Ulinnuha, Rekonstruksi Metodologi Kritik Tafsir, h. 44.

${ }^{28}$ Abdullah Saeed, Interpreting the Qur'an, h. 4. 
Untuk membendung arus absolutisme penafsiran, dibutuhkan suatu pandangan ontologis hakikat tafsir yang bermuara pada pembacaan ulang terhadap produk-produk tafsir yang dipandang otoritatif. Dibutuhkan keberanian dan keseriusan dalam rangka menanyakan kembali keabsahan maupun kebenaran dalam sebuah tafsir. Keberanian tersebut didasari oleh adanya suatu kenyataan bahwa, bagaimanapun agungnya seorang mufasir, tetaplah dia adalah seorang manusia yang memiliki keterbatasan dalam memahami alQur'an. Karena sebagai sebuah penafsiran, proses selama menafsir akan senantiasa dipengaruhi oleh konteks latar belakang sosio-kultural dan keilmuan bahkan "kepentingan" masing-masing mufasir. ${ }^{29}$ Artinya sebuah penafsiran tidak benar-benar mengandung kebenaran mutlak. Tafsir tidak lebih dari sekadar sebuah jihad intelektual yang berusaha untuk menterjemahkan pesanpesan Tuhan bagi manusia.

Tafsir sebagai sebuah hasil ijtihad dan kreasi seorang mufasir, tidak mustahil di dalamnya disusupi berbagai bentuk kepentingan. Tafsir yang diwarnai secara kuat oleh background keilmuan dan ideologi mufasir, dapat disinyalir tidak lagi objektif. Maka sebenarnya, sebuah tafsir selalu berangkat dari kepentingan, tidak ada penafsiran yang benar-benar objektif, absolut dan universal. Meskipun bukan berarti terjebak pada subjektivisme dan relativisme total. Menolak objektivitas total bukan berarti penafsiran menjadi arena bebas bagi subjektivitas dan relativitas, dalam artian penafsir bisa mendekati teks dan menafsirkannya sesuka dan sekehendaknya. Menurut Abdullah Saeed, penafsiran bagaimanapun masih memiliki batasan-batasan metodologis dan aturan yang melahirkan kaidah-kaidah yang harus dipatuhi oleh seorang mufasir, seperti; 1) mengacu kepada penafsiran Nabi Muhammad; 2) memperhatikan konteks kelahiran teks; 3) memperhatikan peran pembaca (reader); 4) memahami hakikat teks; 5) memahami konteks kultural. ${ }^{30}$

Sementara itu, Khaled Abou el-Fadl menetapkan sejumlah prasyarat bagi mufasir dalam menafsirkan al-Qur'an dengan menawarkan model pembacaan hermeneutika negosiatif untuk mengendalikan subjektivitas dan kepentingan

${ }^{29}$ Farid Esack, Qur'an, Liberation, and Pluralism; An Islamic Perspective of Interreligious Solidarity againts Oppression (Oxford: Oneworld Publications, 1997), h. 50.

${ }^{30}$ Abdullah Saeed, Interpreting the Qur'an, h. 149. 
mufasir. Menurut el-Fadl, pembacaan secara negosiatif berarti penafsir tidak saja hanya mengungkap makna teks yang terkadung di dalamnya, tetapi juga dapat membongkar kepentingan yang tersimpan di dalam teks. Maka, dalam proses pembacaan tersebut, seorang reader harus memiliki lima syarat untuk menjaga objektivitas dan mengendalikan libido subjektivitasnya yaitu; 1) kejujuran intelektual (honesty/amanah); 2) kesungguhan (diligence/ijtihad); 3) komprehensivitas (comprehensiveness/shumuliyah); 4) rasionalitas (reasonableness /ma'qüliyah); 5) pengendalian diri (selfrestraint/dabtal-nafs). ${ }^{31}$

Berangkat dari paradigma pemikiran di atas, dapat disimpulkan bahwa, secara ontologis, hakikat tafsir bermuara pada dua aspek yaitu; 1) tafsir sebagai proses (interpretation as process); dan 2) tafsir sebagai produk (interpretation as product). Tafsir sebagai proses bertumpu pada dasar bahwa al-Qur'an itu berlaku universal dan bersifat șāliḥ li kulli zamān wa makān, maka al-Qur'an harus selalu dijadikan sebagai landasan moral-teologis dalam rangka menjawab problem-problem sosial-keagamaan di era saat ini. Sedangkan tafsir sebagai produk bertumpu pada dasar bahwa al-Qur'an adalah petunjuk bagi umat manusia (hudan li al-nās). Sebuah paradigma ontologis yang memandang bahwa al-Qur'an merupakan respon Tuhan atas kondisi (problem) umat manusia. Sehingga kehadiran al-Qur'an harus disambut dengan cara selalu memproduksi makna-makna yang digali dari al-Qur'an sebagai jawaban dan petunjuk umat manusia dalam kehidupan sehari-hari. ${ }^{32}$

Tafsir sebagai proses (interpretation as process), berimplikasi pada sebuah penafsiran yang tidak mengenal kata final dan harus dilakukan secara terus menerus (continue). Artinya bahwa sebuah kerja penafsiran harus senantiasa berlanjut dan tidak boleh berhenti, melainkan harus selalu berproses seiring dan sejalan dengan tuntutan dan kebutuhan zaman. Maka dari itu, al-Qur'an harus ditafsir secara terus menerus demi kepentingan manusia, sehingga tidak kehilangan relevansinya dengan perkembangan zaman. Ini juga berarti bahwa, meskipun selama ini telah banyak berbagai produk kitab tafsir dengan segala kebesarannya, tidak perlu ada sakralitas terhadapnya. Kitab-kitab tersebut tidak lebih dari sekadar refleksi terhadap kondisi-kondisi yang dihadapi oleh sang mufasir ketika itu. Maka, sakralitas terhadap tafsir al-Qur'an hanya akan

${ }^{31}$ Khaled Abou El-Fadl, Speaking in God's, h. 116-120.

${ }^{32}$ Abdul Mustaqim, Pergeseran Epistemologi Tafsir (Yogyakarta: Pustaka Pelajar, 2008), h. 5-8. 
menyebabkan dinamika pemikiran umat Islam mengalami stagnasi, karena perbuatan tersebut termasuk ke dalam "syirik intelektual". 33

Tafsir sebagai proses (interpretation as process) juga membawa konsekuensi logis bahwa, al-Qur'an harus selalu dikaji ulang, ditafsirkan, dan diperbarui, sebab al-Qur'an adalah teks bahasa yang secara mandiri tidak dapat membangun peradaban dan tidak pula mampu memancangkan ilmu pengetahuan dan kebudayaan. Peradaban dan kebudayaan dibangun oleh dialektika manusia dengan realitas di satu pihak, dialognya teks di pihak lain. Peradaban dan kebudayaan dibangun oleh dialektika manusia dengan realitas dengan segala struktur yang membentuknya: ekonomi, sosial, politik, dan budaya. ${ }^{34}$ Sehingga tafsir akan sangat terbuka untuk dikritisi dan dikaji ulang, sesuai dengan tuntutan dan kebutuhan setiap zaman. Sebab seorang mufasir hanya berkedudukan sebagai "pencari kebenaran", bukan "penentu kebenaran" itu sendiri secara mutlak. ${ }^{35}$

Sementara itu, tafsir sebagai produk (interpretation as product) berimplikasi bahwa al-Qur'an adalah pedoman hidup yang harus dikaji dan ditafsir sebagai petunjuk hidup umat manusia. Hasil atau produk pemikiran (muntaj alfikr) ini kemudian dikenal sebagai kitab tafsir. Yaitu sebuah kitab yang menghimpun hasil ijtihad seseorang berupa keterangan-keterangan terhadap maknamakna al-Qur'an yang sifatnya asing dan sulit dipahami. Penafsirannya pun dilakukan dengan cara menggunakan seperangkat alat dan kemampuan ilmu pengetahuan yang dimiliki oleh setiap mufasir. ${ }^{36}$ Sehingga tafsir cenderung sebagai manifestasi kebutuhan manusia yang dilakukan dengan cara mendialektikakan teks (al-Qur'an), pembaca (umat manusia), dan realitas (konteks kehidupan). Maka, betapapun teks yang ditafsirkan adalah suci, tetapi hasil interpretasinya sudah tidak suci lagi. Karena telah masuk ke dalam "disket pemikiran" manusia, sehingga teks suci tersebut tereduksi untuk dapat masuk ke dalamnya, kemudian bercampur dengan usaha pemikiran manusia, sehingga hasilnya tidak lagi "asli ilāhiyyah" atau bersifat insāniyyah. Sebagaimana keter-

\footnotetext{
${ }^{33}$ Nasr Hamid Abu Zayd, Tekstualitas al-Qur'an; Kritik terhadap Ulumul Qur'an, terj. Khoiron Nahdliyyin (Yogyakarta: LKiS, 2013), h. 9.

${ }^{34}$ Ibid., h. 1.

${ }^{35}$ Abdul Mustaqim, Pergeseran Epistemologi Tafsir, h. 3.

${ }^{36}$ Badr al-Dīn al-Zarkashi, al-Burhān, h. 22.
} 
batasan dan kerelativitasan manusia, maka apapun yang diproduksi oleh manusia menjadi relatif dan terbatas. ${ }^{37}$

Tafsir sebagai produk (interpretation as product) merupakan hasil dari pemikiran manusia, yang bersifat historis, relatif, temporal, dan tentatif. Sehingga, setiap hasil penafsiran siapapun dapat dipertanyakan (baca: dikritisi) ulang relevansinya terhadap perkembangan zaman. Dengan demikian, dapat disimpulkan bahwa hakikat tafsir sebagai produk adalah sebuah pemahaman atau interpretasi seorang mufasir terhadap teks al-Qur'an yang sangat terkait dengan konteks sosio-kultural baik yang sifatnya internal maupun eksternal. Konteks internal berupa latar keilmuan, orientasi, kepentingan, beban psikologis dan teologis. Sedangkan konteks ekternal berupa kondisi sosial-budaya, politik dan ekonomi. Dalam hal ini berarti penafsir telah mengantongi prior text yang menyebabkan kandungan teks itu menjadi "tereduksi" dan "terdistorsi" maknanya. ${ }^{38}$

\section{E. Konstruksi Metodologi Kritik Tafsir}

Kritisisme merupakan sesuatu yang niscaya, karena sifat dasar manusia senantiasa menginginkan perubahan ke arah yang lebih baik. Salah satu aspek terpenting dalam melakukan perubahan adalah bersikap kritis. Kritisisme meniscayakan adanya proses dialektika yang dinamis. Pemikiran kritis selalu menekankan pada penilaian reflektif dan kritik. Karena itu, pemikiran kritis memungkinkan kita untuk membaca dan memahami realitas dalam perspektif yang luas dan beragam untuk diarahkan kepada reformasi maupun reformulasi terhadap produk-produk pemikiran. Sehingga, pemikiran kritis merupakan suatu cara untuk mencoba memahami kenyataan, kejadian (peristiwa) dan pernyataan yang ada di balik makna. Semangat kritisisme inilah yang sejatinya diajarkan oleh al-Qur'an dengan menyeru umat manusia untuk secara totalitas menggunakan nalar atau pemikirannya (akal). Bahkan al-Qur'an secara eksplisit mengkritik komunitas masyarakat dan agama-agama lain yang dipandang sebagai ajaran menyimpang. ${ }^{39}$

${ }^{37}$ Abdul Mustaqim, Pergeseran Epistemologi Tafsir, h. 18.

38 Amina Wadud, Qur'an and Women; Rereading the Sacred Text from a Woman's Perspective (New York: Oxford University Press, 1999), h. 5.

${ }^{39}$ Mun'im Sirry, Sciptural Polemics; The Qur'an and Other Religion (New York: Oxford University Press, 2014), h. 45. 
Meneladani kritisisme al-Qur'an, pada akhirnya membuat kritisisme penafsiran al-Qur'an menjadi lahan garapan baru dalam studi al-Qur'an. Tradisi kritik tafsir adalah buah manis dari perjalanan panjang pergulatan al-Qur'an dengan sejarah kemanusiaan. Embrio kritik tafsir yang telah dimulai sejak masa Nabi Muhammad, harus menjadi bidang garapan baru bagi para sarjana alQur'an. Sebagaimana telah disampaikan di awal bahwa secara genealogis tradisi kritisisme sesungguhnya memiliki akar sejarah yang kuat dari khazanah keilmuan Islam. Meskipun istilah 'kritik/naqd' belum digunakan, tetapi cukup memberikan landasan bahwa kritisisme penafsiran telah mentradisi. ${ }^{40}$

Sementara itu, dimensi kritik tafsir mengimplikasikan adanya pengandaian sesuatu yang ideal. Artinya seorang kritikus tidak hanya berhenti pada satu dimensi pemaknaan yang tunggal. Dia senantiasa menggali dan mencari berbagai alternatif kemungkinan dalam pemikiran tafsir. ${ }^{41}$ Karena dalam konteks kritisisme penafsiran al-Qur'an, adalah berusaha untuk menempatkan alQur'an sesuai dengan fungsinya yakni hudan li I-nās (petunjuk bagi umat manusia) serta rạ̣matan li al-'ālamīn (rahmat bagi alam semesta). Maka, secara garis besar kritik tafsir yang harus dikembangkan adalah metode kritik konstruktif. Yaitu sebuah bangunan metodologis yang bertujuan untuk membangun dan mengevaluasi sebuah produk penafsiran agar menjadi lebih baik. Sebuah metodologi mutakhir untuk memotret, menelaah, menguji dan mengevaluasi sebuah produk penafsiran agar terhindar dari bias-bias penafsiran yang menyimpang. Oleh karena itu, kritik tafsir konstruktif harus mengacu kepada hal-hal berikut; 1) bersifat ilmiah dan objektif; 2) bertujuan untuk membangun (memperbaiki) karya tafsir; 3) menjadi bahan acuan untuk meningkatkan personalitas penafsir dan kreatifitas penafsiran. ${ }^{42}$

Di samping itu, proses kritisisme penafsiran juga harus dilandasi dengan prinsip dan parameter yang jelas dalam melakukan kiritik. Sehingga terhindar dari sikap apologis dan destruktif. Tujuan kritik tafsir adalah untuk mengungkap dan menampilkan sisi-sisi yang positif dan negatif dari sebuah produk penafsiran. Hal ini dilakukan untuk menghindari adanya absolutisme penafsiran, yang hanya akan menjadi penghambat kreatifitas penafsiran itu sendiri. Karena

\footnotetext{
40Muhammad Ulinnuha, Rekonstruksi Metodologi Kritik Tafsir, h. 75.

41Komaruddin Hidayat, Memahami, h. 177.

42Muhammad Ulinnuha, Rekonstruksi Metodologi Kritik Tafsir, h. 48.
} 
itu, dalam proses pelaksanaan kritik harus dilandasi dengan prinsip dan parameter yang jelas dan akademis, sehingga kritikus tidak jatuh dalam kesalahan dan subjektivitas yang berlebihan. ${ }^{43}$

Sebagaimana prinsip dan parameter kritik pada Skema 1, seorang kritikus tafsir harus memperhatikan aspek prinsip dan parameter tersebut untuk mendapatkan objektivitas dalam menilai sebuah produk tafsir. Poin-poin di atas bersifat integral, artinya dalam memberikan penilaian seorang kritikus tidak boleh mengabaikan salah satu aspek tersebut. Hal yang terpenting adalah, seorang kritikus harus menguasai disiplin ulumul Qur'an dan ilmu sosial humaniora sebagai pisau analisis dalam membedah dan menimbang suatu tafsir. ${ }^{44}$ Bahwa aspek-aspek di atas, bukanlah sesuatu yang final, artinya aspek di atas masih dapat ditambah demi tercapainya objektivitas penilaian. Kritisisme penafsiran membutuhkan usaha serius. Seorang kritikus harus menghindarkan diri dari berbagai tendensi dan kepentingan dalam menilai sebuah tafsir. ${ }^{45}$ Meskipun keterpengaruhan sejarah baik internal maupun eksternal tidak bisa dihindarkan. ${ }^{46}$

Sementara itu, dalam melakukan kerja kritik tafsir dibutuhkan perangkat metodologi. Yaitu suatu cara, prosedur atau langkah-langkah ilmiah dan sistematis untuk melakukan analisis, evaluasi dan penilaian terhadap produk penafsiran al-Qur'an. Sebagai sebuah diskursus baru dalam studi al-Qur'an, memang belum banyak ditemukan metodologi yang bisa digunakan untuk mengkritik tafsir kecuali sekadar pemikiran sporadis yang tercecer di berbagai karya para sarjana al-Qur'an. Terutama pemikiran yang berbasis pada khazanah intelekual Islam. ${ }^{47}$ Sehingga, dibutuhkan usaha serius dan sistematis dalam menyusun, mengintegrasikan dan mensistematisasikan metode-metode yang telah ada menjadi satu bangunan utuh. Karena, untuk menjadi sebuah disiplin ilmu yang mandiri, membutuhkan suatu rumusan metode yang aplikatif dan ilmiah. Adapun kerangka kerja metode kritik tafsir berikut ini disarikan dari berbagai sumber terutama lebih banyak mengambil inspirasi dari buku M.

\footnotetext{
43Muhammad Ulinnuha, Rekonstruksi Metodologi Kritik Tafsir, h. 53.

${ }^{44}$ Nasr Hamid Abu Zayd, Tekstualitas al-Qur'an; Kritik terhadap Ulumul Qur'an, h. 3.

${ }^{45}$ Muhammad Husain Adz-Dzahabi, Al-Tafsir, h. 25.

46Farid Esack, Qur'an, Liberation, h. 76-77.

47Muhammad Ulinnuha, Rekonstruksi Metodologi Kritik Tafsir, h. 16.
} 
Ulinnuhal. ${ }^{48}$ Metode berikut ini hanyalah satu dari sekian varian dalam kritik tafsir, sehingga masih terbuka lahan-lahan garapan baru untuk menggarap metodologi kritik tafsir yang lebih baik dan aplikatif.

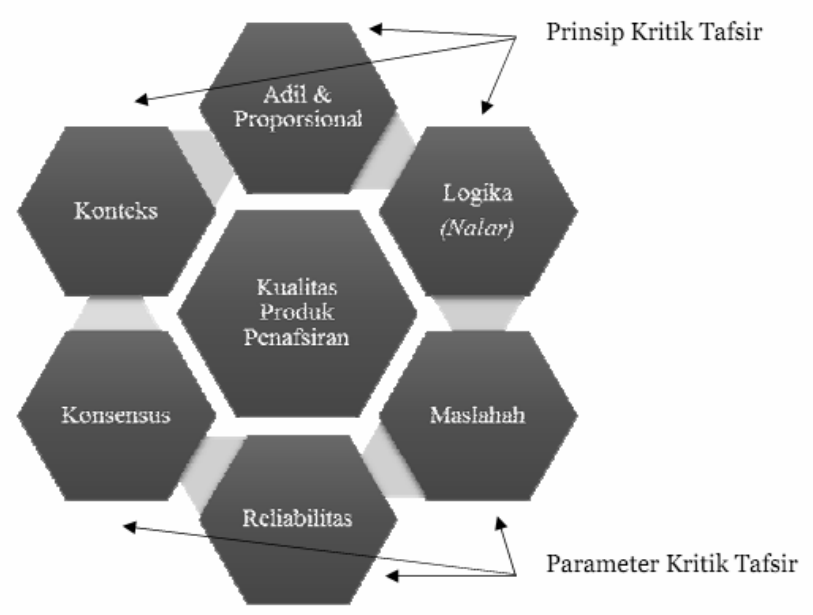

Skema 1.

Prinsip dan Parameter Kritik Tafsir

Berdasarkan skema alur kerangka kerja kritik tafsir (skema II), yang harus dipahami bahwa tiap-tiap komponen bersifat integral dan gradual. Artinya dalam proses melakukan kritik tafsir, tidak bisa dilakukan secara acak dan parsial. Karena setiap komponen bersifat gradasi dari prinsip filsafat ilmu yakni; ontologi, epistemologi dan aksiologi. Dimensi ontologis meniscayakan akan prapemahaman terhadap hakikat tafsir, yang merupakan pijakan awal dalam melakukan kritik. Paradigma seorang kritikus harus terlebih dahulu menolak argumen absolutisme penafsiran. Sehingga, dalam melakukan kerja-kerja kritik tidak akan "dihantui" oleh genangan-genangan logosentrisme ortodoksi pemikiran. Pada dimensi ini, perhatian seorang kritikus dipusatkan pada pembangunan paradigma dalam membentuk struktur keragka berfikir kritis dalam memandang tafsir.

48Muhammad Ulinnuha, Rekonstruksi Metodologi Kritik Tafsir. 
Selanjutnya, dimensi epistemologis merupakan bentuk aktualisasi dari paradigma kritis dalam memandang sebuah produk tafsir. Aktualisasi ini berupa pemahaman dan kemauan untuk melakukan kritik dengan jalan memahami konstruksi kritik tafsir. Artinya, sebagai langkah operasional, seorang kritikus harus memahami bangunan metodologis serta landasan dan tujuan dilakukan-

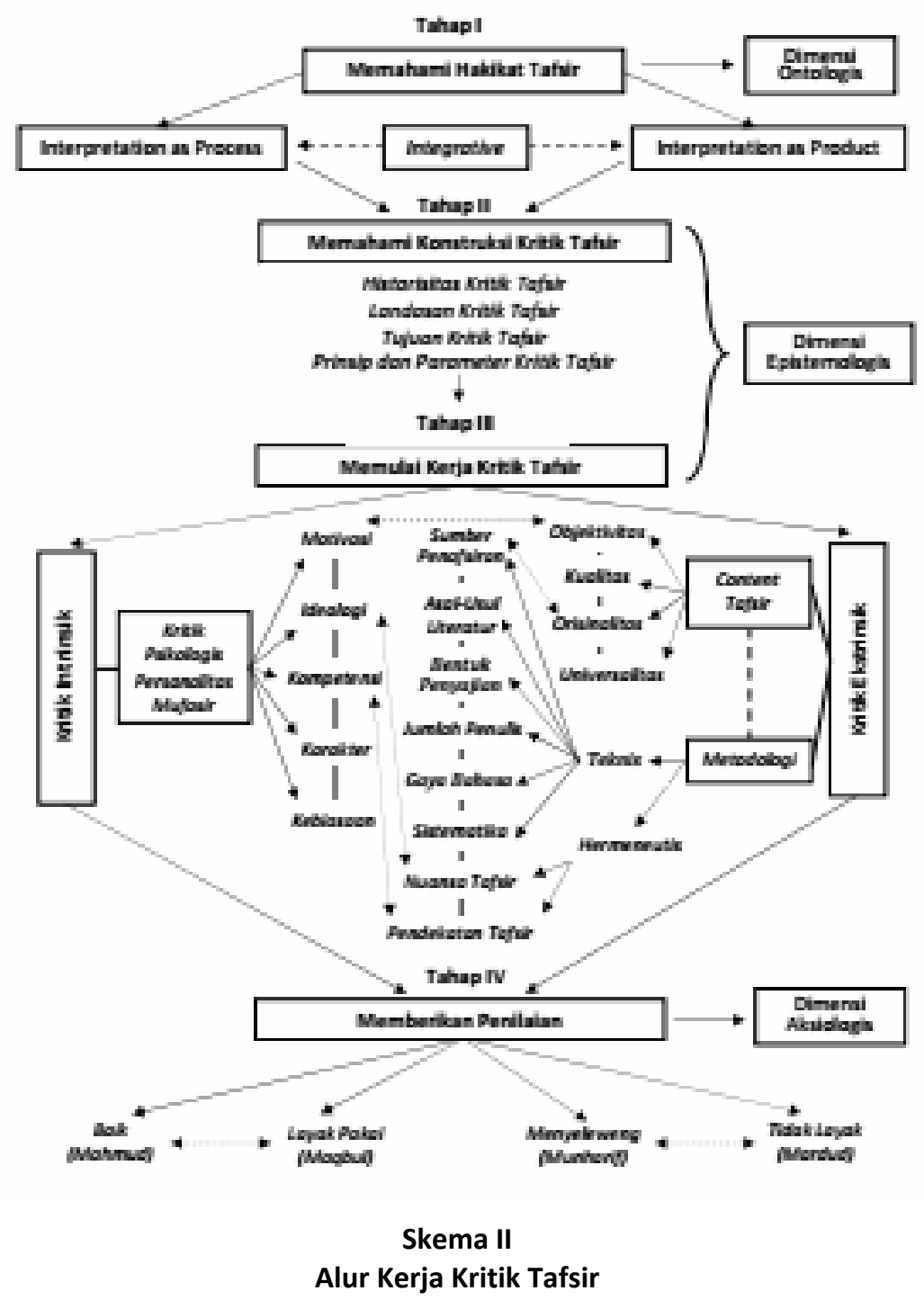

JURNAL THEOLOGIA — Volume 28, Nomor 1, Juni 2017 
nya kritik tafsir. Pada dimensi ini seorang kritikus harus memperhatikan hal-hal yang mengitari teks (dirāsah mā hawl q-naș) dan hal-hal internal yang ada di dalam teks (dirāsah mā fi १-naș). Seorang kritikus juga harus bersifat aktif dan interaktif terhadap segala macam penafsiran. Artinya, kritikus bukanlah seseorang yang bersifat pasif yang begitu saja 'menerima' makna-makna yang telah ditafsirkan. Kritikus juga memiliki peran aktif dalam memproduksi makna teks. Sehingga prinsip kerja kritik tafsir di atas sangat menekankan pada wilyah koprehensivitas, validitas dan objektivitas dalam penilaiannya.

Sedangkan dimensi aksiologis merupakan pantulan atau refleksi terhadap kerja kritik tafsir yang telah dilakukan. Seorang kritikus harus mampu memberikan evaluasi sekaligus penilaian terhadap sebuah penafsiran, dengan memberikan catatan-catatan konstruktif. Pada tahapan akhir ini, seorang kritikus selain memberikan penilaian, juga harus mampu melakukan rekonstruksi terhadap penafsiran yang lalu. Sehingga, pada dimensi aksiologis inilah, seorang kritikus diuji objektivitasnya dalam melakukan penilaian. Apakah akan mengungkapkan sesuai dengan temuannya, atau justru mengingkarinya.

\section{F. Kesimpulan}

Tradisi kritik tafsir sebagai diskursus baru dalam studi al-Qur'an, secara meyeluruh belum banyak diminati oleh para sarjana al-Qur'an. Di samping karena terdapat kecenderungan untuk mengabsolutkan sebuah penafsiran dan anggapan "tabu" jika sebuah penafsiran dikritik. Juga disebabkan oleh, miskinnya metode baku yang dapat digunakan dalam melaksanakan kerja kritik tafsir. Padahal, kritisisme penafsiran merupakan tonggak awal membangun dinamisasi dan perkembangan keilmuan. Bahkan kritik tafsir sejatinya telah dimulai sejak masa Nabi, meskipun masih bersifat embriotik. Sehingga, meluasnya objek kajian al-Qur'an menjadikan wacana Qur'anic Studies semakin berwarna dan tidak monoton. Mulai dari studi tokoh mufasir, studi metode tafsir, studi tematik ayat, hingga living Qur'an dan yang terakhir adalah studi kritik tafsir, telah cukup memberikan warna dalam peradaban Islam. Oleh karena itu, pemahaman kita dalam hal "kritik tafsir" harus dipandang sebagai usaha yang positif-konstruktif. Maka, agenda kritisisme penafsiran al-Qur'an sesungguhnya meniscayakan sebuah konsensus bahwa, seorang mufasir tidak boleh sewenang-wenang dalam melakukan penafsiran terhadap al-Qur'an.] 


\section{DAFTAR PUSTAKA}

Abrams, M. H. and Geoffrey Galt Harpham, A Glossary of Literary Terms, Ninth Edition, USA: Wadsworth Cengange Learning, 2012.

Abu Zayd, Nasr Hamid, Tekstualitas al-Qur'an; Kritik terhadap Ulumul Qur'an. terj. Khoiron Nahdliyyin, Yogyakarta: LKiS, 2013.

al-Dzahabi, Muhammad Husain, al-Tafsìr wa 'l-Mufassirūn, Juz I, Kairo: Maktabah Wahbah, 2000.

Ahmad bin Faris bin Zakaria, Abu al-Husain, Mu'jam Maqāyis al-Lughah, Juz IV, Tahqiq, Muhammad Harun, Beirut: Dar al-Fikr, 1979.

al-Banna, Gamal, Evolusi Tafsir; Dari Jaman Klasik hingga Modern, terj. Novriantoni Kahar, Jakarta: Qisthi Press, 2005.

al-Farmawy, Abu Hayy, al-Bidayah fi al-Tafsir al-Mawdhü'i, Kairo: Matba'ah alHadarah al-Arabiyah, 1990.

al-Zarkasyi, Badr al-Din, al-Burhān fi 'Ulūm al-Qur'ān, tahqiq Ahmad Ali, Qahirah: Dār al-Hadīth, 2006.

Arkoun, Mohammed, al-Fikr al-Islāmī; Naqd wa Ijtihād, Aljazair: Al-Mu'assasash al-Wataniyah li al-Kitab, 1988.

Baldick, Chris, The Concise Oxford Dictionary of Literary Terms, New York: Oxford University Press, 2001.

El-Fadl, Khaled Abou, Speaking in God's Name; Islamic Law, Authority, and Women, London: Oneworld Publication, 2014.

Esack, Farid, Qur'an, Liberation, and Pluralism; an Islamic Perspective of Interreligious Solidarity againts Oppression, Oxford: Oneworld Publications, 1997.

Habib, M. A. Rafey, a History of Literary Criticism; From Plato to the Present, United Kingdom: Blackwell Publishing, 2005.

Harb, Ali, Kritik Kebenaran, terj. Sunarwoto Dema, Yogyakarta: LKiS, 2004.

Harpham, Geoffrey Galt, The Character of Criticism, New York: Routledge, 2006. 
Hidayat, Komaruddin, Memahami Bahasa Agama; Sebuah Kajian Hermeneutik, Jakarta: Paramadina, 1996.

Holman, C. Hugh, a Handbook to Literature, Fourth Edition, Indianapolis: ITT Bobbs-Merrill Educational Publishing Company, 1985.

Jansen, H. James, a Glossary of John Dryden's Critical Terms, Mineapolis: University of Mennesota, 1969.

Jansen, J. J. G., the Interpretation of the Koran in Modern Egypt, Leiden: E.J. Brill, 1974.

Kant, Immanuel, Critique of Pure Reason, trans. Paul Guyer and Allen W. Wood, New York: Cambridge University Press, 2000.

Manzur, Ibn, Lisān al-Arab, Beirut: Dār al-Ma'rifah, 1979.

Mustaqim, Abdul, Pergeseran Epistemologi Tafsir, Yogyakarta: Pustaka Pelajar, 2008.

Rahman, Fazlur, Islamic Methodology in History, Islamabad: Islamic Research Institute, 1995.

Saeed, Abdullah, Interpreting the Qur'an; Towards a Contemporary Approach, New York: Routledge, 2006.

Sirry, Mun'im, Sciptural Polemics; The Qur'an and Other Religion, New York: Oxford University Press, 2014.

Tim Penyusun Kamus Pusat Bahasa, Kamus Bahasa Indonesia, Jakarta: Pusat Bahasa Departemen Pendidikan Nasional, 2008.

Ulinnuha, M, Rekonstruksi Metodologi Kritik Tafsir, Jakarta: Azzamedia, 2015.

Wadud, Amina, Qur'an and Women; Rereading the Sacred Text from a Woman's Perspective, New York: Oxford University Press, 1999. 